\title{
LOCAL SECURITY AS AN ELEMENT OF LOCAL DEVELOPMENT. CASE STUDY OF INFRASTRUCTURE AND ENVIRONMENTAL VARIABLES OF THE CITIES IN THE EASTERN POLAND MACRO-REGION
}

\author{
Paweł DZIEKAŃSKI*, Juljusz PIWOWARSKI,** \\ *The Jan Kochanowski University (JKU) in Kielce, Poland, \\ ** University of Public and Individual Security APEIRON, Krakow, Poland \\ pdziekan@interia.eu
}

\begin{abstract}
The authors in this article present performance of public administration which concerns a basic process developing in the context of dynamics of security culture phenomenon that involves the use of local potential (including infrastructure, natural environment, finance, human capital). The process of development of a region is multifaceted. It involves any changes that are implemented at different paces and with varying intensity in economic, social, technical and environmental areas. Local security is a resulting category that allows to assess functioning of local economy. The aim of the article is to provide determinants that shape security at the local level in the context of the selected elements of the region's balance (infrastructure and environment aspects) by the case of Swietokrzyskie Voivodeship municipalities for 2010 and 2015. In the calculations the data of the Central Statistical Office (Local Data Bank) were used. The determined synthetic measure allows to make hierarchy according to the adopted variables. It supplies information on the examined category of objects. It provides a comparative picture between the objects that were analysed, allows to indicate weaker and better areas of functioning of a unit. As it is shown in the article it gives a basis for the assessment of the effectiveness of the instruments of local authorities policy that were used in the past. The carried out statistic studies confirm existence of disparities in financial condition (financial security) of municipalities.
\end{abstract}

Keywords: local security, synthetic measure, infrastructure, natural environment, city

\section{Introduction}

The management of a regions means taking actions which aim at triggering a desired course of processes and phenomena within a territorial government, the effect of which is the development of a region. A territorial government is a very important element, not only social, but also socio-cultural and economic both in the scale of a region and the whole scale. The tasks, they implement, are of non-profit nature, which results in the fact that they are financed from public resources $[8,16]$. The area of own tasks of a municipality include categories of technical and social infrastructure, public order and security and of spatial and ecologic order. Social expectations and need grow while the resources the territorial government units dispose of are limited, which in turn causes the need to use rational and effective methods of public resources management.

The process of region's development is of multidimensional nature. It includes all the transformations taking place at various pace and with different intensity in the economic, social, technical and environmental sphere. The development encompasses, however, not only the transformations of quantitative nature, but also of qualitative and structural essence [9]. Strategic management reduces and 
eliminates significantly the threats, which are a direct result from the internal conditions or from the external surroundings of the state [18].

\section{The aim and method research}

The aim of the study is to assess the spatial differentiation of synthetic measure of local security on the example of the cities of Eastern Poland macroregion. The data from Central Statistical Office (Local Data Bank) - in the area of infrastructure and environment - for 2010 and 2014 were used for the calculations. 70 cities were evaluated, with a particular focus on 14 cities with county rights, which were described in the detailed analysis.

Using selected variables (table 1c) taxonomic indicators of economic security of municipalities were constructed. In order to do that, a following, simple taxonomic procedure was used $[11 ; 7]$ :

1. Statistical analysis of diagnostic features. The elimination of features closely correlated with each other was done. Diagonal elements of the reverse matrix R-1 far exceeds the value of 10 , which suggests a bad numeral conditioning of the matrix R. X1, X2, X4 were removed from the research. $[10 ; 2 ; 12]$. Features should indicate appropriate variability. Variables, for which the threshold value of the measure $=0.10$, were eliminated from the set.

2. Bringing data to mutual comparability (zero unitarization method; [13]). Destimulant was converted into stimulant by the formula:

$$
X_{i j}:=\frac{1}{x_{i j}}
$$

where $X_{i j}$ - feature of number $\mathrm{j}$, describing objects $x_{i}, j=1,2 . . p$ (p- number of features); $\mathrm{x}_{\mathrm{ij}}-$ value of the object of number $\mathrm{i}$ $(i=1,2 . . n)$ for $X_{j}$ feature of number $j$ $(j=1,2 . . p ; n / p-$ number of objects). Stimulants were standardized according to the equation: $z_{i j}=\frac{x_{i j}-\min _{i} x_{i}}{\max _{i} x_{i}-\min _{i} x_{i}}$

where: $i=1,2, \ldots N ; j=1,2, \ldots, p$ ( $N$ is the number of objects (municipalities), and $\mathrm{p}-$ number of features); $z_{i j}$ - refers to the unitarized value of the feature for the studied unit, $x_{i j}-$ refers to the value of $j$ feature for a studied unit, max - maximum value of $\mathrm{j}$ feature, min - minimum value of $\mathrm{j}$ feature [10].

3. Calculation of the value of the synthetic measure of economic security 1) based on the distance in the real space with a Euclidean metric given with the formula:

$E D_{i t}=\sqrt{\frac{\sum_{j=1}^{p}\left(1-z_{i j t}\right)^{2}}{p}}$

2) based on the distance in the real space with an urban metric:

$U D_{i t}=\frac{\sum_{j=1}^{p}\left|1-z_{i j t}\right|}{p}$

where: ED/UD - synthetic measure in the studied period, zij - features of the structure of synthetic index, $p$ - number of features [3]. Indexes (3)/(4) take values from the range $[0,1]$. The higher the value, the worse the situation.

4. Linear organizing of objects and a selection of typological groups (according to the value of quartiles).

5. Verification of mutual compatibility of the achieved results (Pearson, R. Spearman, t-Kendall, Gamma correlation coefficients), analysis and interpretation of the results, forming conclusions $[4 ; 5 ; 1]$.

\section{The activating function of the environment and infrastructure}

The complex nature of the phenomenon of local security causes the fact that the efficient activities in this aspect should be implemented in a complex, coordinated and orderly way, using a coherent set of methods and technical and organizational measures. The proper functioning of the security system that is able to identify threats and counter them is essential. It should be implemented in every phase of 
designing, planning, construction and exploitation of local infrastructure, as well as possible to apply at all levels of management: strategic, tactical and operational [19].

In the process of development of the regions, infrastructure is one of the elements of creation of the economic activity, it conditions its range, structure and spatial distribution, or it determines the attractiveness or lack of it in the case of a given region, and, therefore, determines the opportunities and barriers of its further development. The condition to maintain or improve the competitive position of local government is, among other things, good condition of infrastructure and the development of it, as well as the quality of the natural environment. These factors may affect significantly the competitiveness of a given social and economic space.

State of the environment and the measures taken to protect it are more and more treated as a significant factor of competitiveness. Natural environment is, inter alia, a source of obtaining raw materials and energy, it provides space for entrepreneurship, a place for living or recreation [14]. Natural environment may also be seen as heritage which, on the one hand, is an effect of civilizational development, and, on the other hand, which is conditioning this development $[15,17]$.

The phenomenon of the culture of security is characterized by emergentism. It is based on the emergence of qualitatively new - in relation to the initial factors of three foundations - types of behaviours. It is the result of the interactions between these analytically separated factors. The culture of security is the whole of settled tangible or intangible acquisition of a human serving broadly understood, militarily and non-militarily, autonomous defence of certain individual and group entities. The field of security culture enables the operator who is in it to pursue: 1) The control of the threats, in order to achieve the state of low level of threats. 2)
Recovery of security when it has been lost. 3) Optimization of multi-sector security by harmonious, adjusted to the needs proportions of the development of its sectors. 4) Stimulating the needs of the harmonious development, activation of motivation resulting in individual and collective action for the development of individual and group security entities [19].

\section{Synthetic measure of infrastructure and the environment}

The level of development of the infrastructure of a given local system, in terms of its structure, location, quality and availability, has a very strong influence on its development. For it determines the investment costs of the local development, in other words, investment costs of the development concerned with enterprises, development of social infrastructure and the environmental protection.

The value of the security measure fluctuated in case of ED method from 0.46 (Lublin) to 0.78 (Krosno; in 2010); from 0.44 (Lublin) to 0.77 (Krosno; in 2014). In case of UD method from 0.31 (Lublin) to 0.72 (Krosno; in 2010); from 0.28 (Lublin) to 0.70 (Lomża; in 2014; table 1b). The best cities due to the level of security measures were Lublin, Rzeszów, Kielce (2010; ED/UD) and Olsztyn (2010; UD); Lublin, Rzeszów, Białystok (2014; $\mathrm{ED} / \mathrm{UD})$. At the other end of the rank Łomża, Krosno (2010, 2014; ED/UD; table $1 b)$.

The evaluation of the ED measure indicates the decrease of 3 units, increase of 2 units and the same position of 9 units (Chełm, Krosno, Lublin, Rzeszów). The most favourable changes of position in 2014 in comparison to 2010 were reported in Białystok (from 5 to 3), Zamość (from 10 to 9). The biggest drop of ranking position in 2015 in comparison to 2010 took place in Biała Podlaska (from 9 to 10); Kielce (from 3 to 4), Olsztyn (from 4 to 5). In case of UD method - 2 units improved their position (Białystok; from 4 to 3; Krosno; from 14 to 13); 2 units 
worsened their position (Łomża: from 13 to 14; Olsztyn: from 3 to 4), 10 units did not change position (Kielce, Lublin, Rzeszów, Tarnobrzeg).

In order to assess the differences in the level of financial condition in the analyzed years and to define whether these differences increased of changed, the analysis of standard deviations and the range and the minimum and maximum value of the measure were used, among other things (table 1b). The average value of the synthetic measure in 2010 amounted 0.66 and it decreased slightly in 2014 0.64 , for ED measure and 0.58 in 2010 and 0.56 in 2014 - for UD measure. In 2014, in comparison to 2010, the differentiation according to the taxonomic measure, did not change (standard deviation +0.004 for $\mathrm{ED} ;+0.01$ for UD), with the simultaneous increase of the range from 0.322 in 2010 to 0.335 in 2014 (for ED; 0.40 to 0.42 from UD; table $1 b$ ).

Table 1: Quartile groups for taxonomic measures of economic security and correlation measure

a) coefficient of correlation of taxonomic measure and its

transformations

\begin{tabular}{|l|c|c|}
\hline \multirow{2}{*}{} & \multicolumn{2}{|c|}{ ED-UD } \\
\cline { 2 - 3 } & 2010 & 2014 \\
\hline Pearson & 0.990 & 0.990 \\
\hline R Spearman & 0.986 & 0.986 \\
\hline Gamma & 0.956 & 0.934 \\
\hline Tau Kendall & 0.956 & 0.934 \\
\hline \multirow{2}{*}{ ED-dED } \\
\cline { 2 - 3 } & 2010 & 2010 \\
\hline Pearson & 0.376 & 0.458 \\
\hline R Spearman & 0.276 & 0.420 \\
\hline Gamma & 0.172 & 0.372 \\
\hline Tau Kendall & 0.168 & 0.361 \\
\hline \multirow{2}{*}{ UD-dUD } \\
\cline { 2 - 3 } & 2010 & 2010 \\
\hline Pearson & 0.467 & 0.841 \\
\hline R Spearman & 0.258 & 0.641 \\
\hline Gamma & 0.172 & 0.511 \\
\hline Tau Kendall & 0.168 & 0.497 \\
\hline
\end{tabular}

c) variables describing local security

$\mathrm{x} 1$ population using waste water treatment

$\mathrm{x} 2$ population using water supply system

$\mathrm{x} 3$ population using sewage system $\mathrm{x} 4$ population using gas network $\mathrm{x} 5$ length of active water supply network

$\mathrm{x} 6$ length of active sewerage network

$\mathrm{x} 7$ green areas (ha)

$\mathrm{x} 8$ nature monuments

$\mathrm{x} 9$ area of forest land

$\mathrm{x} 10$ waste generated during a year

$\mathrm{x} 11$ water consumption per capita

$\mathrm{x} 12$ effluent during a year

$\mathrm{S}$ - stimulant; D- destimulant b) quartile groups of taxonomic measures of security

\begin{tabular}{|c|c|c|c|c|}
\hline & \multicolumn{2}{|c|}{ ED } & \multicolumn{2}{|c|}{ UD } \\
\hline & 2010 & 2014 & 2010 & 2014 \\
\hline $\begin{array}{c}\text { A } \\
\text { very good }\end{array}$ & $\begin{array}{l}\text { Lublin0.458 } \\
\text { Rzeszów } 0.498 \\
\text { Kielce } 0.551 \\
\text { Olsztyn } 0.556 \\
\text { Białystok } 0.567 \\
\text { Elbląg } 0.617 \\
\text { Przemyśl } 0.705 \\
\text { Tarnobrzeg } \\
0.711 \\
\text { Biała Podlaska } \\
0.733 \\
\text { Zamość } 0.734 \\
\text { Suwałki } 0.741 \\
\text { Chełm } 0.746\end{array}$ & $\begin{array}{l}\text { Lublin } 0.437 \\
\text { Rzeszów } 0.502 \\
\text { Białystok } 0.522 \\
\text { Kielce } 0.536 \\
\text { Olsztyn } 0.547 \\
\text { Elbląg } 0.619 \\
\text { Przemyśl } 0.664 \\
\text { Tarnobrzeg } \\
0.717 \\
\text { Zamość } 0.722 \\
\text { Biała Podlaska } \\
0.729 \\
\text { Suwałki } 0.739 \\
\text { Chełm } 0.743\end{array}$ & $\begin{array}{l}\text { Lublin } 0.311 \\
\text { Rzeszów } 0.406 \\
\text { Olsztyn } 0.467 \\
\text { Białystok } 0.485 \\
\text { Kielce } 0.487 \\
\text { Elbląg } 0.497 \\
\text { Przemyśl } 0.634 \\
\text { Tarnobrzeg } \\
0.638 \\
\text { Biała Podlaska } \\
0.661\end{array}$ & $\begin{array}{l}\text { Lublin } 0.283 \\
\text { Rzeszów } 0.377 \\
\text { Białystok } 0.425 \\
\text { Olsztyn } 0.459 \\
\text { Kielce } 0.469 \\
\text { Elbląg } 0.497 \\
\text { Przemyśl } 0.579 \\
\text { Tarnobrzeg } \\
0.629 \\
\text { Biała Podlaska } \\
0.660\end{array}$ \\
\hline $\begin{array}{c}\text { B } \\
\text { good }\end{array}$ & $\begin{array}{l}\text { Łomża } 0.773 \\
\text { Krosno } 0.780\end{array}$ & $\begin{array}{l}\text { Łomża } 0.769 \\
\text { Krosno } 0.772\end{array}$ & $\begin{array}{l}\text { Zamość } 0.677 \\
\text { Suwałki } 0.680 \\
\text { Chełm } 0.693 \\
\text { Łomża } 0.706\end{array}$ & $\begin{array}{l}\text { Zamość } 0.662 \\
\text { Suwałki } 0.678 \\
\text { Chełm } 0.691 \\
\text { Krosno } 0.697 \\
\text { Lomża } 0.700\end{array}$ \\
\hline $\begin{array}{c}\mathrm{C} \\
\text { weak }\end{array}$ & - & - & Krosno 0.716 & - \\
\hline $\begin{array}{c}\mathrm{D} \\
\text { bad }\end{array}$ & - & - & - & - \\
\hline Minimum & 0.46 Lublin & 0.44 Lublin & 0.31 Lublin & 0.28 Lublin \\
\hline Maximum & 0.78 Krosno & 0.77 Krosno & 0.72 Krosno & 0.70 Łomża \\
\hline Range & 0.32 & 0.34 & 0.40 & 0.42 \\
\hline $\begin{array}{l}\text { Quartile } \\
\text { range }\end{array}$ & 0.18 & 0.20 & 0.19 & 0.21 \\
\hline Variability & 0.17 & 0.18 & 0.23 & 0.25 \\
\hline $\begin{array}{l}\text { Standard } \\
\text { deviation }\end{array}$ & 0.11 & 0.11 & 0.13 & 0.14 \\
\hline
\end{tabular}

ED measure based on Euclidean distance; UD measure based on urban distance; dED - dUD dynamics of transformations of the measure

In figure 1 the correlograms describing the transformation of the security index and relations between the taxonomic their level were presented. 

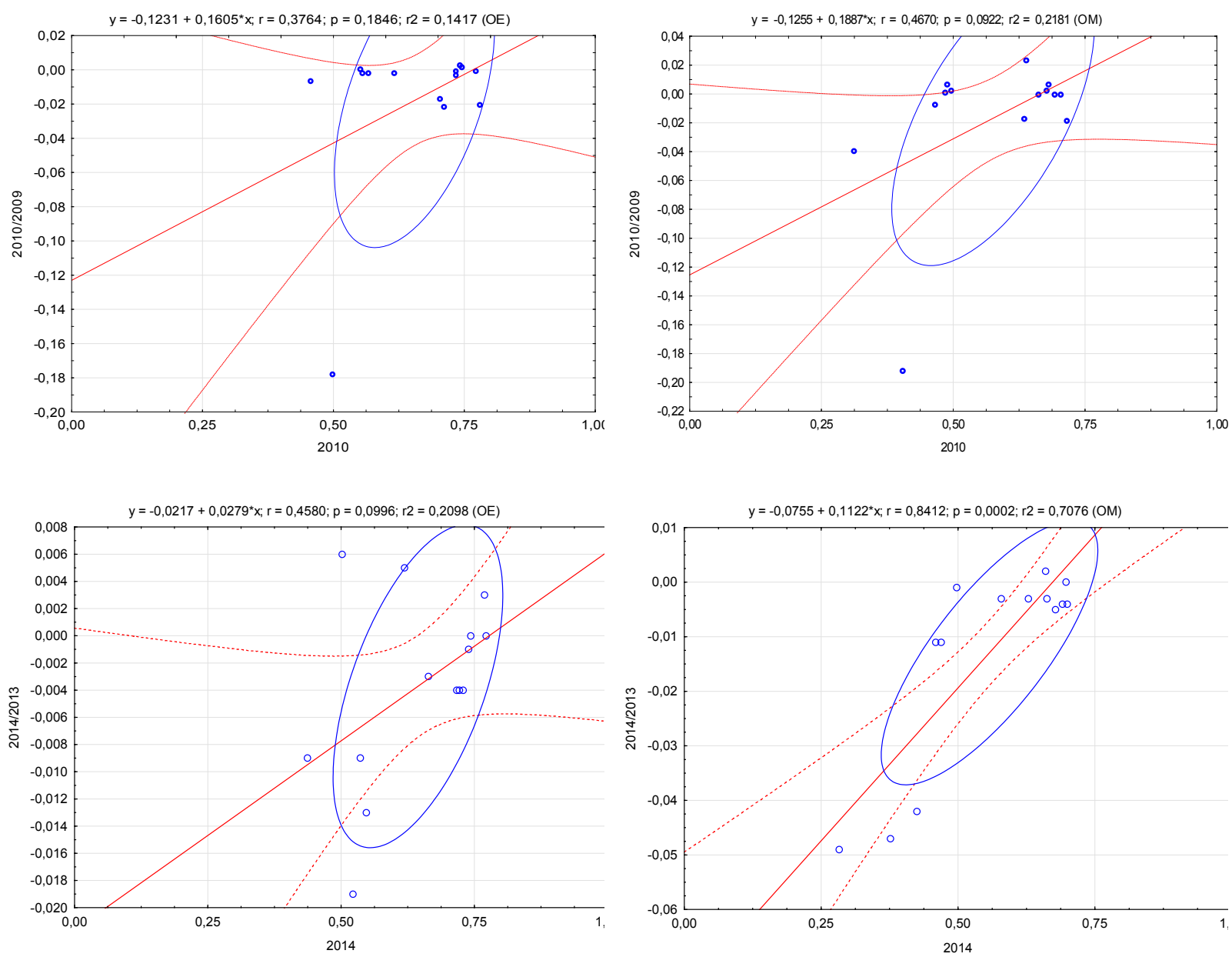

Figure 1: Relative transformation of taxonomic measure of security of a region (in the aspect of infrastructure and environment; in 2010 and 2014).

A conclusion can be drawn from them that the measures of security, based on the Euclidean and urban distances, were subjected to divergence in the years 20102014 (the coefficients of Pearson correlation between their relative changes in the studied period of time and their level amounted $0.376-0.458$ for ED; 0.467 0.841 for UD).

\section{Conclusions}

The development of infrastructure, which is the potential of $3 r d$ foundation of security culture at the local level comes across a lot of difficulties. An important limitation is the level of own financial resources and the selection of proper investment priorities. Investment expenses are to increase the living standard of the residents and enable the municipality to implement public tasks [6].
The information owned, related to the state of infrastructure, may be used to plan the development of the region, to implement the regional policy and to take decisions connected with allocation of funds as part of implemented activities. The value of the synthetic measure obtained here depends from the quantity and the types of variables taken for research.

The method used enables to compare the degree of attractiveness of one municipality in regard to another. The measures achieved depend from the quantity and type of variables taken for study. They give a comparative picture between the analyzed municipalities, enabling the indication of weaker and better areas of functioning of an administrative unit. These measures also enable to add it to a proper class, in terms of financial condition. 


\section{References}

[1] Dziekański P., Spatial Differentiation of the Financial Condition of the Siwiętokrzyskie Voivodship Counties, Barometr Regionalny, Tom 14 no. 3, pp. 79-91, 2016.

[2] Walesiak M., Problemy selekcji $i$ ważenia zmiennych $w$ zagadnieniu klasyfikacji, PN AE we Wrocławiu, Taksonomia 12, pp. 52-71, 2005.

[3] Kościelniak P., Szewczyk M.W., Tokarski T., Taksonomiczne wskaźniki rozwoju ekonomicznego województw i powiatów, Wiadomości statystyczne, 9, p. 75-97, 2014.

[4] Hellwig Z., Zastosowanie metody taksonomicznej do typologicznego podziału krajów ze względu na poziom rozwoju oraz zasoby i strukturę wykwalifikowanych kadr. Przegląd Statystyczny 15.4.1968

[5] Zeliaś A., Malina A., O budowie taksonomicznej miary jakości życia. Syntetyczna miara rozwoju jest narzędziem statystycznej analizy porównawczej, Taksonomia z. 4, 1997.

[6] Woźniak A., Zemanek J., Analiza dochodów budżetowych $w$ aspekcie poziomu rozwoju infrastruktury technicznej gmin, Infrastruktura i Ekologia Terenów Wiejskich, PAN, No. 3/2, pp. 193-205, 2006.

[7] Dziekański P., Wykorzystanie wskaźnika syntetycznego do oceny poziomu rozwoju samorzadu na przykładzie gmin wiejskich województwa świętokrzyskiego, [in:] S. Owsiak (edit.), Determinanty rozwoju Polski. Finanse publiczne, PTE. Warszawa, pp. 261-279, 2015.

[8] Gorynia M., Łaźniewska E. (edit.) Kompendium wiedzy o konkurencyjności, Wyd. Nauk. PWN, Warszawa, p. 181, 2009.

[9] Fiedor B., Kociszewski K. (edit.), Ekonomia rozwoju, Wydawnictwo Uniwersytetu Ekonomicznego we Wrocławiu, Wrocław, 2010

[10] Wysocki F., Lira J., Statystyka opisowa. Wyd. AR im. A. Cieszkowskiego, Poznań, 2005

[11] Tokarski T., Statystyczna analiza regionalnego zróżnicowania wydajności, zatrudnienia $i$ bezrobocia w Polsce, Wydawnictwo PTE, Warszawa, 2005.

[12] Młodak A., Analiza taksonomiczna w statystyce regionalnej, Difin, Warszawa, pp. 28-32, 2006.

[13] Kukuła K., Metoda unitaryzacji zerowanej. PWN, Warszawa, 2000.

[14] Żylicz T., Ekonomia wobec problemów środowiska przyrodniczego, PWN, Warszawa, 1989.

[15] Bernaciak A., Gaczek W.M., Ekonomiczne aspekty ochrony środowiska, Poznań, p. 15-16, 2002

[16] Olak A.,Globalizaćne faktory ohrozujuce sućasnu rodinu/Factors of globalizations endangering contentamporary family [in:] BEZPEČNOSTNÉ FÓRUM, Zborník vedeckých prác SECURITY FORUM 2016. Banská Bystrica II. Zväzok /II. Volume, p. 723-742, 2016.

[17] Olak A., Jurcak V., Wptyw czynników zewnętrznych na zmiany w organizacji [in:] (ed.) A. Limański, Róża Milic-Czerniak, Konkurencyjność podmiotów gospodarczych $i$ jej determinanty. WSZMiJO w Katowicach. Katowice 2014. p. 259-272.

[18] Dukiewicz T., Spustek H. Informacja $w$ zarzadzaniu strategicznym [In:] ZN Politechniki Śląskiej, seria Organizacja i Zarządzanie, Politechnika Śląska, nr 92, p. 61-71, 2016.

[19] Piwowarski J., Transdyscyplinarna istota kultury bezpieczeństwa narodowego, Wydawnictwo Naukowe Akademii Pomorskiej w Słupsku, Słupsk, p. 297, 2016. 